\title{
Forgotten Border Actors: the Border Reinforcers. A Comparison Between the U.S.-Mexico Border and South American Borders
}

\author{
Alejandro Grimson, Universidad de Buenos Aires and \\ Pablo Vila, University of Texas at San Antonio
}

\section{Introduction}

This article is a critique of two different types of essentialisms that have gained widespread acceptance, both academically and politically, in places as distant as the U.S.-Mexico border and different Mercosur frontiers. Both essentialisms rely on metaphors that refer to the concept of union, and put their emphasis on a variety of sisterhood/brotherhood tropes and, in particular, the crossing metaphor. Thus, it is quite frequent to hear people talking about border peoples' fraternity in the American Southern Cone as well as the brotherhood or the lack of conflict that characterizes the relationships between Mexican nationals, Mexican immigrants, and Mexican Americans on the U.S.-Mexico border (G.Anzaldúa 1987; H.Calderón and J.D.Saldívar 1991; A.Paredes 1978; G.Recondo 1997; R.Rosaldo 1989; J.D.Saldívar 1997; Various Authors $1997 \mathrm{a}$; b). The border crosser metaphor, at the same time, has been widely used to make sense of something that could be described as the "new historical subject"1 , and as a paradigm to think about intercultural exchanges in general (H.K.Bhabha 1994; G.Gómez-Peña 1988, 1991; M.Harrison and M.E.Montoya 1998; E.Hicks 1991). These and similar metaphors, such as one that states borders "only exist on the maps," (R.Abínzano 1993:76), have something in common. They obscure the social and cultural conflict that often characterizes political frontiers, independent of the physical separation that borders can create through ethnically homogeneous groups like the Mexicans on the U.S.-Mexico border. Nullifying conflict as a central dimension of border life impedes visualizing the asymmetric relations between sectors, groups, and states, and the growing dynamics of exclusion.

Those metaphors are used mainly by literary/postmodern border theorists but also by some social scientists and historians as well. Thus, in the case of the U.S.-Mexican border, although those metaphors were popularized by authors that did not do any ethnographic work on the border (see G. Anzaldúa 1987; G.Gómez-Peña 1988, 1991; E. Hicks 1991; R.Rosaldo 1989; J.D.Saldívar 1997), some well respected anthropologists and historians, such as Carlos VélezIbañez and Oscar Martínez, have written splendid accounts of the U.S.-Mexico border where the conflict between Anglos and Mexicans occupies center stage. The intra-ethnic conflict between Mexican nationals and Mexican Americans, however, is either denied or sharply downplayed. Consider for instance, Vélez-Ibánez's outstanding work (1996). Although the book is a very skillful description of everyday life on the U.S.Mexico border, it has only a paragraph and a footnote that refer very superficially to the conflict that exists between Mexican Nationals and Mexican Americans exemplified by the use of the slur pocho (a highly Americanized Mexican) by the former to refer to the later. In Oscar Martínez's notable books $(1978,1994)$ about the border something similar occurs. In the earlier work (1978), he mentions several areas of conflict between Anglos and Mexicans: the Free Zone, the U.S. possible military intervention against Pancho Villa, the depression of salaries by commuter workers from Juárez, the reaction against undocumented immigrants since the great depression. He does not, however, mention any conflict between Mexican nationals and Mexican Americans even though some of his own data show that such conflict was present. ${ }^{2}$ Therefore, it is not by chance that he advances his own version of the border

1. The Mexican or Central American immigrant in the U.S. is perhaps the best example of this usage (P.Vila 2003).

2. In pages 107-108 of his Border Book Town, Martínez quotes at length some Juarenses' 
Alejandro Grimson and Pablo Vila

as a "third country," pointing out that "a large portion of Juárez's population might be considered 'Chicanos del lado mexicano' (Chicanos who live on the Mexican side)" (O.Martínez 1978:155).

A similar, albeit more nuanced stance is present in Martínez' otherwise wonderful Border People (1994). The book leans toward multiculturalism and hybridity as characterizing the U.S.Mexico border in general and Mexican Americans in particular:

The most salient characteristic of Mexican American borderlanders is the intensity of their transnationalism, which is not surprising, because powerful historical forces have shaped a profound and enduring relationship with the Mexican side. Of the three major groups discussed in this work [Anglos, Mexicanos, and Mexican Americans], Mexican Americans most closely resemble a transborder population, people whose living space transcends an international boundary. In many ways they are an inbetween population, caught between competing ways of life and contrasting worldviews ... Their adjustment to a dual way of life has been eased by direct and substantial participation in the shaping of the trans-boundary system in which they function [O.Martínez 1994:116].

What part of this quotation prepared potential readers interested in border dynamics to the profound anti-Mexican stance expressed by many Mexican Americans regarding Operation Blockade? None.

Obviously, not everyone doing empirical studies on the U.S.-Mexico border has been influenced by the above-cited metaphors. A good example is Heyman (1994) who reminds us that (until 1994 at least) no ethnographic works about identity construction were done on both sides of the border simultaneously that declare a hybrid subjectivity or identity is the epitome of border identity. He further states that "the limited evidence we do have . . . indicates that the Mexican borderlander's subjectivity remains strongly Mexican" (J.Heyman 1994:46; see also J.Heyman 2001). ${ }^{3}$ Heyman himself does a very good ethnographic study of the Border Patrol's officer of Mexican ancestry in El Paso (J.Heyman 2002). There are some other authors who either address the conflictive character of the border or the ethnic and racial tensions that characterize the American Southwest, like David Gutierrez (1995), and George Sanchez (1995). Works by Manuel Peña, $(1985,1999)$ reveal class and ethnic strife between Mexican Americans and Mexicanos on the border. More recently ethnographies by Scott Cook, (1998) and Alan Klein (1997) both illustrate ethnographically the conflicting relations and resulting problems of people on the border. For instance, Cook found out in his research on Reynosa, that the "strong sense of Mexican identity/nationality among 'Norteños' belies the 'pocho' or 'agringado' labeling they routinely suffer at the hands of Mexicans from the interior" (S.Cook 2002:221). Klein's Baseball on the Border (1997) is also a welcome addition to an emerging corpus of ethnographies that move beyond the hegemonic crossing borders metaphor we criticize in this article. His analysis of the intertwining of autonationalism, binationalism, and transnationalism is very illuminating; where "the river joins, and the river divides" is the expression many Laredoans use to convey the complexity of border social relationships. Although Baseball on the Border is a very important book, it does have its limitations. One is that although it goes against the current North American border studies approach we criticize here, it is still trapped by some of its problems. We are referring here to the trend to look at the border mostly from the American side of the divide.

testimonies in which the denial of true "mexicanidad" to the pochos is quite clear but does not merit Martínez's analysis.

3. Pablo Vila, in different studies (1996, 1997, 1998, 2000 and 2003) has tried to fill that ethnographic void for the Ciudad Juárez-El Paso border. 
Forgotten Border Actors: the Border Reinforcers

In the Southern Cone, less empirical research has been done on the region, and the little that has been done is less crystallized in well-defined trends. Latin American essentialism is a grand narrative that includes, with little ethnographic work, history, culture, and borders (for instance H.Clementi 1996, and G.Recondo 1997). Several empirical studies on the region, however, have repeatedly avoided the analysis of border conflicts. This avoidance has concealed a key dimension of border life, resulting in a reaffirming of the "regional integration from below," by which, supposedly (and going well beyond the conflict hypothesis of their respective nation states), border people have demonstrated their "brotherhood" (e.g., R.Abínzano 1993 and E.Mazzei 1999). Of course we also have in the Mercosur case, ethnographers who portray borders with all the conflicts and complexities that characterize them, like Ribeiro (1994), Ferradas (1998), Vidal (2000), Gordillo (2000) and others included in Grimson (2000). ${ }^{4}$

In sum, we believe that in an effort theoretically and politically oriented to deconstruct national identifications, several scholars have excessively emphasized the "nonexistence" of borders for the local populations involved, constructing a frozen image preceding the construction of the state in the Mercosur border case, or the Mexican-American war, in the case of the U.S.Mexico border (where Chicanos used to say that they did not cross the frontier, but that the border "crossed them"), as if the constant interventions of the state and its complex operations would never have significantly affected or involved the local populations. This romantic and essentialist version has impeded the comprehension of the cognitive, political, economic, and cultural relevance of the state and the nation to those borders.

This article wants to reemphasize this conflictive dimension that we think is key to any ethnography about borders. In that regard we will analyze two different case studies and search for similarities and differences between the U.S.-Mexico border and a particular border of the Southern Cone. The first case study is the history of a bridge constructed between Posadas (Argentina) and Encarnación (Paraguay). The second case study is the community reaction toward an operation implemented by the Border Patrol in 1993 (Operation Blockade) at a border that for many years was considered an exemplar of the "good-neighbor relationships" between Mexico and the United States, the frontier between the "sister cities" (a trope in itself, see P.Vila 2000) of El Paso, Texas, and Ciudad Juárez, Chihuahua.

\section{The Bridge that Separated Two Shores: Posadas (Argentina) and Encarnación (Paraguay)}

"The vice-minister has to bring effective solutions, if she doesn't, we will close the bridge (with all of you there) for an undetermined period of time and to the last consequences," exclaimed the president of the Association of Taxi and Truck Drivers of Encarnación (Paraguay) in a meeting organized on the bridge that unites the Paraguayan city with Posadas (Argentina).It was the last instance of the ninth "blockade" of the bridge performed, on this occasion, by the Paraguayan workers who make a living moving people and goods throughout the border: taxi drivers and "paseras" (ferrywomen or couriers-Paraguayan women who "pass" merchandise from the Paraguayan side to sell it in Posadas).

Though the social and cultural history of the Paraná river as a border and crossing point is a long one (see A.Grimson 2002), the warning made by the trade union leader showed how much things had changed since the bridge was inaugurated seven years before. The threat of "closing the bridge for an undetermined period of time and to the last consequences" was in sharp contrast to

4. In other parts of the world as well, some border scholars have tended to analyze neighbor border populations as "communities," minimizing the role of the State, the nation, and the frontier itself (see T.Wilson and H.Donnan 1998 for a critique). On the other hand, several scholars working on European and African borders have emphasized the border reinforcers in their analysis (see A.P.Cheater 1998; P.Sahlins 1989; and E.Tonkin 1994). 
the integrationist rhetoric of its inauguration in 1990. On April 2 of that year the presidents of both countries gathered on the stage located at the international frontier. On the border itself they embraced each other and were photographed by journalists and filmed by TV cameras. Later, the national anthems were sung and both presidents made their speeches. Then, the bishops of both cities blessed the bridge together. Finally, both presidents disentangled the memorial ribbon making the inauguration of the international bridge official.

In the inauguration act, different social participants deployed a discourse about the bridge that emphasized the brotherhood/sisterhood of peoples and nations. Elements of latinoamericanismo (pan-Latin American fraternity) were also present, but above all there was a great expectation about the impact of the bridge on regional economic growth. In such discourses the bridge seemed to condense the possibility of progress for a historically peripheral region, and it was welcomed with auguries of future investments and commercial growth. El Territorio, Misiones most popular newspaper, dedicated a 16-page supplement to the bridge announcing the "Argentinean-Paraguayan integration." The Paraguayan press expressed similar hopes.

The goal of Argentinean President Menem's discourse was to construct a sense of fraternity and progress. The Paraguayan people "can be sure that Argentinean friendship will find in this bridge a new and privileged road for mutual cooperation that will benefit a region whose development has to be designed in common and without borders or distinctions." Paraguayan President Rodriguez pointed his discourse in the same direction: the bridge is "a landmark of perpetual presence in the bonding of our people." To avoid people's suspicions that all those words were mere diplomatic rhetoric, he stressed that "without demagogic rhetoric we have the right to turn symbolic the boundaries of our States to transform our nations into one fatherland."

After the bridge is finally inaugurated, five to seven times the number of people cross the river each year, while 30 to 40 times the number of vehicles cross. This increase transforms the lives of both cities, especially regarding commerce, because the exchange of goods is the most important motive that prompts people to cross the river. Because Posadas and Encarnación, as the majority of the region's border towns, constitute a common market divided by a political frontier, the inhabitants of both cities take advantage of the price differentials in order to maximize their salaries. In recent years, with different variations, prices were lower on the Paraguayan side of the border.

From the beginning, the private importation of gasoline by filling up tanks in Encarnación, was beyond the control of the Argentinean customhouse. Between 1992 and 1995, the number of gas stations in that city tripled. The cheap price of gas, in addition to price differentials that existed in many other products, was used to lure customers to the Paraguayan side of the border,. According to Posadas' inhabitants, when they crossed the bridge to fill up their cars, "taking advantage of the crossing you went to the supermarket" and this increased the number of crossings, which reached its peak between 1994 and 1995. To counteract this trend, in 1997 the Argentinean government decided to reduce gasoline taxes in Posadas so that prices were similar on both sides of the river. This measure increased the selling of gasoline in Posadas by 66 percent.

Calculating the average expenditure of a person who crosses the bridge is quite difficult, but there are clues that it constitutes a significant amount of money. For consumers it improves the value of their salaries, for Posadas' retailers, on the contrary, it means losing customers. Thus, border crossings and customs controls became a focus of dispute intersected by a complex web of conflicting interests, while putting on stage the diverse categories of perception and action of the different social actors involved. Posadas' commercial and business associations made multiple claims "against the asymmetries" and "unloyal competition" of Encarnación's commerce, requiring the national Argentinean government to implement some tax exemption and more customs controls. In more informal settings they affirmed that the bridge was producing "the economic debacle of the city." 
Forgotten Border Actors: the Border Reinforcers

From the point of view of the Argentinean government, however, the commercial exchange with Paraguay did not produce a deficit. On the contrary, it produced a surplus, and Argentinean officials pointed out that a tax exemption would have provoked serious fiscal disarray (see A.Oviedo and J.Gortari 1997:48). Therefore, until 1996, the most important solution to pressure from the merchants' was to order more customs control. This control, sometimes very obsessive, and the contemptible treatment of Paraguayans by the Argentinean customs triggered a conflict that involved many social groups. At one point the conflict acquired diplomatic status as well, when both the Foreign Minister and the Paraguayan President demanded the removal of an Argentinean customs official.

In 1992, when taxi drivers and paseras faced new obstacles in the Argentinean customs, community protests, claims, and rallies became habitual. But where could they go to make their claims visible on both shores simultaneously? The bridge. Therefore, when Argentinean customs did not allow them to pass, paseras sat down on the bridge and blocked traffic, forcing people and vehicles that wanted to cross to the other side of the river to wait until the protest was over.

During a blockade staged in August, 1992, some Argentinean citizens coming back from Encarnación became desperate enough to attempt to cross the border on foot, bypassing the Paraguayans who blocked it. One woman grabbed an Argentinean flag. Many followed her, and everybody started to move forward. Paraguayan police tried to stop them and fired warning shots. A military policeman insulted by those involved in the incident, snatched the flag from the woman; the group that followed her started to shout at him. A Paraguayan official ordered the officer to return the flag so that calm could be restored until the blockade was lifted.

At the border itself, rights were disputed in national terms. A group of Paraguayan workers-identified by the Argentineans as one of the groups linked to the small-scale smuggling operations called contrabando hormiga - decided to interrupt traffic to claim what they considered their rights. Those who attempted to cross any way were trying to transform their social location from foreigners to natives and vice-versa.

The situation worsened when more conflicts erupted and became more virulent. Not only did different border institutions and diverse Paraguayan social groups participate in the dispute, but gradually, Posadas' merchants, local political authorities, and even the Presidents of Argentina and Paraguay became involved.

In 1993 the blockades became more frequent and lasted longer. Tension grew over the river in the frontier itself. Paraguayan taxi drivers denounced the increase in restrictions in Argentinean customs. As one taxi driver stated, "regional integration doesn't exist, but only occurs in people's mouths, but not in practice." A representative of the taxi drivers added, "the bridge is for everybody or it is for nobody." The paseras blockaded the bridge some weeks later, denouncing physical and verbal abuse by Argentinean customs.

The chief of the Argentinean customs pointed out that controls would continue to be implemented rigorously "no matter that some people have to be overlooked and search for other ways of making ends meet." He also absolutely denied the existence of "malos tratos" [abuse against Paraguayans], explaining that his agents only did their jobs "following the severity of the law." In these statements, there is clearly a kind of double meaning regarding the Paraguayan's charge of Argentinean' mistreatment. On the one hand, there were never-ending arguments about whether the Argentinean customs stripped Paraguayan paseras, took away their merchandise, or even beat them. On the other hand, there was a remarkable inability by Argentineans to perceive that their demand that paseras search for "other ways of making ends meet" was one of the most intolerable mistreatments.

This articulation of power, class, and nationality is complemented by a gender overtone. The Argentinean State and its different agents have historically produced the border as a space of economic and political risk, and of important mass-mediated disputes, where cultural relations are traversed by the dangers implicit in a widespread, erotic, and wild metaphor: that of the virgin 
lands culturally penetrated. The construction of the motherland as a victim seeks through an effective presence of the state to avoid the persistent and future penetration of the "neighbors." At the same time, the peculiarity of Misiones in the Argentinean map and national imaginary is that it can be defined as an Argentinean wedge that "penetrates" Brazilian and Paraguayan territories.

From the point of view of paseras and other Paraguayan actors, the moral scandal became apparent when Argentinean customs (males) beat paseras (females). An extreme case occurred when Argentineans forced a Paraguayan citizen (male) to-literally-pull his pants down on the pretext of searching for (penetrated with) smuggled merchandise. The violence of nudity (for the Argentinean males a warrant that the frontier will not be violada [violated/raped]), working as an extreme analogy of the power asymmetries between nationalities and genders, produced the moral indignation of Paraguayans. In this way, during the conflict, a constant ambiguity between the feminization and masculinization of the border was produced. Thus, Argentineans constantly pointed out that one of the most important problems of the region was that the national territory was continuously "penetrated" by foreigners: Paraguayan merchandise, illegal immigrants, and also "cultural penetration" through radio and television stations of neighboring countries. To the point that such a discourse portrays them as "victims," Argentineans construct themselves as "feminine," using many references to "powerlessness" to frame the situation. However, this discourse of risk, penetration, and rape also justifies a violent and "masculine" control of the border, which is exemplified in the beating of paseras (females) and the compelling of the Paraguayan citizen to undress himself.

From 1994 to 1996 paseras' complaints were increasingly directed toward a customs agent named McLean. One pasera recounted that while attempting to cross the border with vegetables and cigarettes, she tried to escape when she realized that the customs agents would not allow her to pass because McLean had ordered that their merchandize be seized. When the border police saw her, they called her but she told them, "beat me, kill me, but I won't return to the customs house." When McLean caught her, she reported that he "twisted my arm, hit me in the mouth, broke my lip, threw me away and kicked me." Paseras blamed McLean for all their problems: "before he arrived, we worked pretty well," they claim. "Right now we cannot even pass Paraguayan merchandise ... because mister McLean is there." Therefore, the figure of this one Argentinean official seemed to condense all the prohibitions and customs controls, the mistreatments, and discriminations. McLean became the Argentinean customs agent most hated by paseras, the epitome of the Argentinean macho, and they started to demand his removal, accomplishing in the process the support of Paraguayan authorities.

Because of the blockades, people in Posadas were building, step by step, a particular image of the Paraguayans, an image that portrayed them almost like savages, as being the only people who could violate international treaties in such fashion. The Argentinean blockade of the bridge, although seen by many as something "absurd" and "impossible" due to the "sovereignty of the law" that supposedly reigns in that country, finally occurred in late 1995. Argentinean merchants called all Misioneros to follow them against Buenos Aires' centralized politics. The protesters stopped the traffic on the main bridges connecting Argentina with Paraguay and Brazil, showing that the problem was defined precisely around the circulation on the fringes of the nation state. To mark the boundaries was the best way they found to make Argentinean authorities, located more than 600 miles away, hear them. "Put the national flag in the stores," they asked, trying to imbue the claim with a patriotic meaning.

Although the merchants demanded that all Misioneros follow them, the trade unions that opposed the national government because of its neoliberal economic policy, also marched against the government the same day, but for very different reasons. From Posadas' central square they asked to "restore popular power" and not to act "like the merchants who went out to cacarear [cackle] because we are forced to buy on the other side to get more value out of our salary." That is, the trade unions were explicitly distancing themselves from the provincial claim of the 
Forgotten Border Actors: the Border Reinforcers

merchants while identifying themselves with the border crossers who usually buy merchandise in Encarnación.

As we can see, some social actors marked the boundary while others vindicated its crossing. As a result, the merchants' blockade did not have the success they expected. The national government delayed concrete measures through negotiations and meetings without any promise beyond the formulaic "we will try to solve the issue." With the menace of a new blockade on the horizon, a strong political pressure was launched to halt it. Different social sectors came together for the "collective construction of Mercosur" and "dar tiempo al tiempo" [to allow time to set its course].

After the Argentinean blockade, several Paraguayan social groups interrupted the traffic on the bridge several more times. In late 1996, McLean, the hated Argentinean customs agent, was transferred. In early 1997, the Argentinean national government made an important gesture toward local merchants as well: it lowered fuel prices in Posadas to the level of those in Encarnación. The restrictive customs controls and the blockades continued, however; they became natural and routine, generating feelings of resignation.

A political turning point occurred two years later. The pressure exercised by diverse Posadeño groups demanding more customs control not only produced a "hardening" of a border that was supposedly disappearing, but also triggered specific state measures procuring the regulation of border commerce. In 1999, the Argentinean national government modified the border regulations of the country. It decided to reduce drastically the value of the merchandise border inhabitants could introduce into the country. With the new disposition, border inhabitantshistorically subjected to a special regime - could only buy up to $\$ 100$ per month on the other side of the international divide. While trucks and containers could enter without any limits on products of any Mercosur country, the new measure affected workers in general and border workers in particular. In that way, the Argentinean State redefined the frontiers of the regional block.

Because they were severely affected by the measure, different social sectors (Paraguayans and Argentineans alike) that made a living out of bringing merchandise from one side of the border to the other staged several rallies and border blockades during January and February at various border crossings. As a consequence, some provincial governors and border mayors attempted to repeal the new border measure. Therefore, the implementation of the new regulation started to be partially negotiated. Thus, in the midst of a regional integration process that was supposed to make borders disappear, the characteristics of the national frontiers continue to be redefined through this tension among border populations, and between them and the national state. And this occurs against what many academicians and "natives" alike understand as a process of "integration from below" or the "non-existence of borders, except on the maps" (R.Abínzano 1993).

Although in general the new bridges have accelerated the economic exchanges and the movement of people, in the current social and political situation they cannot be perceived as unvaryingly unifying people and countries. On the contrary, the reorganization of the exchange circuits can be articulated with a vision of the bridges as the "cause" of new divisions, new resentments, and disputes. A bridge pieced together with the politics of hardening and reinforcement of borders, such as the bridge between Posadas and Encarnación, can end up separating two shores.

\section{Sister Cities? Ciudad Juárez-EI Paso and the Border Patrol's Operation Blockade ${ }^{5}$}

The above example showed what occurred along one of the Mercosur borders; those who

5. Part of the empirical material of this section has already appeared in P.Vila 2000. 
extensively used the metaphors of border brotherhood, hybrids, crossing borders, and the like to characterize the situation of the U.S.-Mexico border (for some the paradigmatic case of "border crossings") were quite surprised by what happened in 1993 on the border between Ciudad Juárez, Chihuahua and El Paso, Texas. Ciudad Juárez and El Paso were considered for many years to epitomize border friendship. An important part of that characterization came from El Paso's sizeable Mexican population (more than $70 \%$ ). It was assumed by many people that both cities were somehow culturally homogeneous, and that Mexican Americans supported Mexican immigration, whether legal or illegal, out of ethnic loyalty, and because many of them were migrants themselves.

All these myths crumbled on Sunday morning, September 19, 1993, when El Paso and Ciudad Juárez woke up to a new Border Patrol strategy to deter illegal immigration into the United States. A surprise Border Patrol action, Operation Blockade, placed 400 agents and dozens of government vehicles and helicopters on the 20-mile stretch of the border dividing El Paso from Ciudad Juárez. This strategy ended decades of laissez-faire attitudes held by the Border Patrol toward undocumented people, that fed a utopian image of El Paso and Juárez as a model of brotherhood along the border. As a matter of fact, some local people were unaware of the amount of resentment underlying the supposedly "smooth relationships between sister cities." As Salvador Balcorta, director of South El Paso's La Fe Clinic stressed: "The thing we have to overcome now is the hatred . . . For the longest time we have blinded ourselves to the feelings that may be out there." [El Paso Times (EPT), October 3, 1993].

As Howard et al. (1994:6) pointed out: "The hostility and pent-up frustration that had been unleashed by the blockade was astonishing. These feelings had obviously been submerged by the official rhetoric of oneness, by the unspoken assumption that Mexicans and Mexican Americans would naturally sympathize with each other ... that blood was thicker than the water flowing in a river with two names." Different polls showed overwhelming public support for the strategy (80-95\%, depending on the source. EPT, March 20, 1994, 1A.)

What happened? We think that the nationwide anti-immigrant wave current at the beginning of the 1990s was responsible for part of the support the operation received. But part of that support came because the Border Patrol was doing physically what many El Pasoans, both Anglo and Mexican American, had been doing symbolically before: separating themselves from Mexican nationals in order to construct a value narrative identity of people living in the United States.

Some journalists described the feeling of many people in El Paso as euphoria "[as if it were] the best time of our lives. That was the feeling I sensed in El Paso this week as we rallied around our Border Patrol" (J.Laird, EPT, September 26, 1993). Supposedly the Blockade would solve all the social problems of the city, because behind them, of course, many Mexican Americans and Anglos saw the shadow of the "illegal aliens." What were those problems? The Chief of the Border Patrol, Silvestre Reyes, argued that one of the most important reasons for the Blockade was to answer a community demand to clear the city of beggars, auto thieves, burglars, welfare cheats, and "transvestite prostitutes." The opinion of city officials, and El Pasoans' phone calls and letters to the media and newspapers seemed to support that demand. For instance, El Paso's Mayor, Larry Francis, not only was delighted about the possible outcomes of the blockade, but also used the operation to complain to the federal government about the cost the city was paying to provide services for the undocumented: $\$ 30$ million per year, according to his account. Following Francis', many El Pasoans supported the blockade because they appeared to believe that all the beggars and almost all the criminals were Mexicans:

More than 130 people called the El Paso Times Wednesday to express opinions on the Border Patrol's "Operation Blockade." By a 10-to-1 ratio, callers supported the Patrol's action ... A sampling of responses:

John Fernandez: "This is the only way we can deter some of the crime and 
Forgotten Border Actors: the Border Reinforcers

some of the illegals coming into our country."

Robert Muñoz: "I think this is the greatest thing that has happened. I live in an area where there is a lot of illegal traffic and since Sunday I have felt safer about my house."

Ralph Woodbridge: "I'm getting sick and tired of my city being viewed as the city of beggars and panhandlers on every corner" [EPT, September 23, 1993].

Forty-four people called the El Paso Times . . . a sampling of how El Pasoans say the operation is affecting them:

Ernest Alvillar: "I feel much more secure in that I don't have to worry about some illegal alien breaking into my home."

Art Provencio: "For one you don't have people jumping on your car at intersections smearing up your windshield. And I'm sure that crime and car theft has drastically dropped" [EPT, September 24, 1993].

Keeping undocumented immigrants from entering El Paso will benefit the city economically in the long run, according to most of the 132 people who called the El Paso Times with opinions Sunday ... A sampling of responses:

Patty Olivas-:"I think the crime rate and auto thefts will go down dramatically." Michael Bradley: "I think that since the blockade has started, the number of stolen vehicles has gone down. I think that over a long period of time that might mean our insurance rates will drop."

Terry Williams: "I believe the long-term impact will be favorable. We'll have reduced crime, reduced cost of deporting those illegals that are caught, reduced welfare costs, and fewer instances of instant citizens that are born at our expense in our hospitals."

Julia Lopez: "I think the long-term economic impact will be favorable. In fact, my husband and I talked about it and even if our taxes had to go up, it would be worth it. It would be worth it to get all this crime and illegals out from our city" [EPT, September 28, 1993].

We're not seeing people being shot or stabbed or robbed. [After the Blockade] It's different for the better, because now we don't worry about having to look behind and worry about these undocumented immigrants committing crime [F.Morales, Director of Chihuahuita Community Recreation Center, EPT, March 20, 1994].

The complaint that the "illegal aliens" take advantage of the American welfare system was very prominent in several letters to the editor sent several months before the blockade. Therefore, it is not surprising that many people saw in the Blockade the final solution to those abuses:

The long-term effect [of the Blockade] is beneficial because they won't be taking advantage of the welfare system or our schools or any other freebies that are offered to them. Our taxes will go down and we'll save money [C.Jimenez, EPT, September 27, 1993].

I would be happy to pay more taxes so that the blockade will continue permanently ... Thomason Hospital is used to care for illegals. They come to have their babies, who are immediately eligible for benefits such as the WIC [Women, Infants, and Children Program]. Our schools are overburdened by undocumented children. Most of them do not want to speak or will not speak 
Alejandro Grimson and Pablo Vila

English. Our cars are being stolen and our homes burglarized. Thanks to our Border Patrol for doing a great job. Keep it up [J. Del Palacio, EPT, September 30, 1993].

The argument that Mexican undocumented workers were the cause of the high unemployment in El Paso was not forgotten:

[After the blockade] the economy should be looking good because the unemployment in El Paso will go down because more people will be able to get jobs that these Mexican illegals have been getting [M.Arroyos, EPT, September 27, 1993].

And the supposed complicity of Mexican illegal aliens with drug trafficking was also mentioned: El Paso sector Border Patrol Chief, Silvestre Reyes, appeared Friday on Jeff Limberg's radio talk show . . . Only one caller-Robert-protested the blockade. Two subsequent callers caused me to worry. The first said that Robert opposed the blockade because Robert's cocaine dealer obviously had been delayed and thus Robert could not snort a few lines. The second said Robert ought to stick his opinions where the sun does not shine [J.Laird, EPT, September 26, 1993].

And the feeling of safety some El Pasoans experienced after the blockade seems to have changed some well-entrenched domestic habits in the city:

The El Paso Times asked readers if they employ a maid . . . who has been unable to get to work because of the blockade and, if so, how that has affected them. The calls were anonymous. Here's a sampling of responses:

"My maid has not been able to make it across and, surprisingly, I have done very well without her. I was reading in the paper that the maids were saying we lazy Americans were sending our husbands to work with wrinkled clothes. I am ironing my husband's shirt with no problem and I don't need the maid back even if the blockade is over."

"We do have a maid who has not come for the last two weeks. But that's all right, we are all just pitching in and it is worth it for the safety that our children are feeling now in the streets of El Paso" [EPT, October 1, 1993].

The support Mexican Americans showed for the operation was so overwhelming that it changed the discourse of one of the most important Chicano advocates of the city, journalist Joe Olvera. In his weekly column, a month after the blockade started, he wrote one of his most passionate articles ever:

It saddens me the way things are going between El Pasoans and Juarenses. I don't think we're ever going to be friends again. Not that we've ever been really close friends, you know. Our attitude toward Juarenses has always been holier than thou. We, in El Paso, have always lorded it over Juarenses. Even those of us who are of Mexican descent have found it embarrassing that our people in Mexico can't seem to get their acts together. We cringe when we see our people begging on El Paso streets, some of us even lie when we're asked about our own ancestry ... When I was growing up ... we were ashamed to be Mexicans . . . we loved Mexican culture, mariachis, tortillas and frijoles, but sometimes we hated our own people ... "We're more American than some Americans," we say proudly. "We have nothing in common with those illegal aliens who only come here to take our jobs" ... we're such good Americans that we rail against our own brothers and sisters ... "Sure, my ancestors came 
Forgotten Border Actors: the Border Reinforcers

over illegally, but they came to work, not to take the food from other children's mouth. They didn't go on welfare or food stamps." Come on, raza [people]; don't turn against your own people [EPT, October 24, 1993].

If this was the reaction of many El Pasoans to Operation Blockade, what happened in Juárez? There was an initial counter-blockade of the international bridges that was a spontaneous action from the undocumented immigrants themselves. People screaming, "We want work!" halted traffic for a couple of hours. Subsequent actions were implemented by the CDP (Comité de Defensa Popular). This organization was responsible for burning the U.S. flags and Uncle Sam piñatas, while yelling, "Burn gringo, burn! Let all Yankees die!" that so infuriated El Pasoans.

The CDP also initiated a campaign at American maquiladoras that asked American employees to quit the country, and managers to improve salaries to the level of American ones. In late September, only two weeks after the blockade was implemented, much of the initial and violent opposition to the blockade coming from the undocumented themselves or from CDP was gone. As we will see below, the situation of the undocumented workers was not popular among many Juarenses. Nevertheless, a different kind of opposition started, because Juarenses already had discovered the prejudiced ways, exemplified in the letters quoted above, in which many El Pasoans justified the blockade, ways in which not only the "illegal immigrant" was constructed as the "abject, contemptible other," but Mexicans in general and Juarenses in particular. Accordingly, different political and business groups in Juárez asked Juarenses to stop spending money in El Paso. The Juárez offices of the National Chamber of Commerce and the Chamber of Industry joined the city's Institutional Revolutionary Party (PRI), radio disc jockeys, and populist political parties in asking Mexican shoppers to boycott El Paso. As the head of the Juárez office of CANACINTRA (Cámara Nacional de Comercio e Industria de la Transformación [National Chamber of Commerce and Transformation Industry]) pointed out: "We are asking people to find local alternatives to purchases in El Paso so they will not be humiliated by United States authorities at the border crossing" (EPT, September 29, 1993). ". . . Mexicans are tired of being considered thieves in El Paso" (EPT, October 1, 1993).

Juarenses' outrage was expressed in different ways, as in these letters to the newspapers and editorials:

We go there [to the U.S.] to work, not to steal, nor to contaminate their environment with our "stench," as some of our countrymen who are already "legal" say; and perhaps they have forgotten that they were once just as "illegal" as we are-they and all their relatives as well [El Diario de Juárez (EDJ), September 25, 1993].

Operation Blockade is far from being a mere police device, the product of the decision of a country well-disposed to have its laws respected and to defend its sovereignty ... On the contrary ... it constitutes an unmistakable gesture in regard to the value that is accorded to Mexico and its citizens in the U.S. . . . it has succeeded in reopening the old racial wounds and [rekindling] xenophobia on both sides of the river . . . the time has come for Juarenses to defend our dignity and to redefine our role in the context of intercity relations ... no one has the right to treat us like unwelcome guests or non-desired outsiders . . we don't have to claim for privileges, nor the right to violate the laws of a foreign country; but neither do we have to accept being called criminals, thieves or beggars. [EDJ, September 25, 1993].

We don't like each other. Not because of voluntary feelings; rather because of historic reasons. They are our race. They've left for economic reasons. They've 


\section{Alejandro Grimson and Pablo Vila}

left their house. I'm not talking about all Mexican Americans, only about those who lead the struggle against Mexicans. [Héctor González Mocken, president of the Juárez municipal committee of the PRI, cited in C.Howard, I.Carrillo and S.Peregrino 1994:3]

What these political and business groups wanted was a commercial boycott of El Paso, an operation called "Operación Respeto" or "Operación Dignidad." Such a campaign would have required people to consume Mexican products instead of American ones, and promoted slogans such as: "Consuma lo mexicano;" [Consume Mexican Products] "Si quieres ser respetado, quédate en Juárez" [If you want to be respected, stay in Juárez], etc.

Despite all the impetus and support coming from the most important political parties and representatives of the commerce and business communities, the campaign was a total failure. Not only did many Juarenses continue shopping in El Paso, but they also expressed their disapproval toward the measure:

Dora Martínez, a Juárez secretary, said Tuesday she has no plans to stop shopping in El Paso regardless of the Juárez chamber's request. "I don't think it's fair for the people who come to buy groceries or clothes," Martinez said after grocery shopping at Furr's near Bassett Center [EPT, September 29, 1993].

On the one hand, this kind of attitude shows how important it is for some Juarenses to keep their relationships with the other side running smoothly. On the other hand, it explains why the complaint of the undocumented was not a popular issue in Juárez. Consequently, the problem of the undocumented people failed to obtain widespread support among Juarenses, and some of them publicly expressed their criticism against those who blocked the bridges in protest.

"The protesters are probably the ones that cross illegally and for them to ask others not to cross is wrong," Georgina Salas of Juárez said. "They are protesting in vain. If they want to cross, they should get their paperwork and cross legally." [EPT, September 22, 1993].

Juarense Maria Luisa Piñeda, who has a shopping visa to enter El Paso, said Friday that the United States has a right to its border. "And I had to go through a lot of trouble to get my visa. They (Juarenses without visas) should get in line like everyone else," Piñeda said. "Some people like the easy things." $[E P T$, September 25, 1993.]

As we can see, what happened in Ciudad Juárez-El Paso in 1993 cannot be understood with the preferred metaphors of sister cities, border crossers, third country, hybrids, and the like preferred by many current, mainstream border scholars. What we have is a very complex process of reinforcing a border when an American agency decides to take action against the "other." That "abject other," culprit of all the region's problems, is not constructed as such only by Anglos, i.e., the ethnic "other," but also by Mexican Americans and Juarenses, supposed "brothers."

\section{To Reinforce, Cross, or, Use Borders?}

As we have pointed out, in the last decade or so two different perspectives have persistently used the metaphor of the effacing of borders: (1) a globalist perspective that maintains that processes of economic transnationalization are "reflected" in the blurring of national states and borders, both in social and cultural terms; and (2) specific political and academic discourses that stress that, to border actors, those frontiers either never existed or are in the process of disappearing. In the Mercosur case, and within the framework of regional integration agreements, this type of discourse points to the "eternal brotherhood/fraternity" of people, proclaiming the end 
Forgotten Border Actors: the Border Reinforcers

of borders toward the construction of the "patria grande"-the great Latin American nation dreamed by San Martín and Bolivar in the nineteenth century. In the case of the U.S.-Mexico border, the Chicano discourse has replaced the myth of Aztlán (the original homeland of the Aztecs, supposedly located in the Southwest), by the image of "the border," site of the encounter and supposed integration of Mexicans and Mexican Americans.

Some scholars, in their attempt to deconstruct the artificial limits between states that many times have divided sociocultural groups, advance the argument that there exists a real integration among those groups, loosing sight of the concrete effects that processes of nationalization and nationalistic policies have had upon the construction of peoples' subjectivities over time. This kind of approach has the great risk, in the Mercosur case, of taking at face value the new political stance of the Southern Cone states and affirming from this the eternal unity of people. A similar risk in North American border studies is to claim, without qualifications, the existence of Mexican-Chicano brotherhood on the border, without taking into account the important resentments that in some cases characterize those intra-ethnic relationships (P.Vila 2000). Pretending to show that national borders are a historical and contingent product, can end up affirming that they only exist on the maps.

Empirical research on the border has shown over and over that frontiers continue to constitute barriers in terms of trade, migration, and identity (for Mercosur see H.Vidal 1998; G.Gordillo and J.M.Leguizamón 1999; for the U.S.-Mexico border see P.Vila 1997 and 2000; and D.Spener and K.Staudt 1998). Borders, as a cultural and political invention, seem to be well prepared to survive the end of the closed national economies era, in particular, those that seem crucial either because they help in the development of differential economic advantages, or because they are functional in the production of national and ethnic identity differences.

These situations points out the dangers of the romantic perspective that tends to essentialize a supposedly trans-border culture and identity that would bring people together. In the Mercosur case, the mere affirmations of a "shared culture" and the absence of inter-border conflict that constitute part of the native's discourse should stir suspicions about their truthfulness. Often times the opposite is true, however (see E.Mazzei 1999). This is so because such native discourse produces the fascination of the ethnographer and can be articulated with the "empirical demonstration" of the absence of state policies. That demonstration, however, presents several problems:

- It is based more on discourses than practices

- When it analyzes both discourses and practices, either it selectively uses those that tend to demonstrate such a "radical autonomy" regarding the state; or, still worse, bypasses some elements that in their own descriptions show the opposite.

- It departs from an ontological and teleological identity conception that presupposes that any ethnic or class identity is always preferable to the distortion imposed by the nation. Therefore, showing the absence of the nation's impact could lead to a (re-) enforcing of such an original identity that, finally, could reveal itself.

Perhaps the most notorious paradox of this conception in the Mercosur case is that it combines the false consciousness idea (coming from traditional Marxism) with populism, the movement that so impacted the region in the last 50 years. Thus, while the nation can be understood as a false consciousness, to criticize its function is not the most important task. Instead, this conception tries to describe the supposed "absence" of the nation, a product, they claim, of the popular sectors' capacity of resistance and autonomous production.

In the case of the U.S.-Mexico border, the Chicano narrative that has recently acquired some power in American universities produces ethnic and class discourses quite similar to the Latin American ones, in this particular case no matter that both the discourses and actions of many 


\section{Alejandro Grimson and Pablo Vila}

border actors of Mexican descent have quite different plots. ${ }^{6}$ Those narratives and actions clearly establish that they do not believe they share an identity with the Mexican people on the other side of the border. Maybe they share some aspects of a culture, but not necessarily an identity (for the difference between sharing a culture and sharing an identity, see P.Vila 2003). Thus in most Chicano border narratives, Mexican citizens of northern Mexico and Mexican Americans living in the Southwest are constructed almost essentially opposed to Anglos. And the name "Mexican" refers to ethnicity and class simultaneously, as if all Mexicans were ethnically similar (ignoring the national, regional and/or ethnic differences within the group), and all belonged to the working class (ignoring the class differentials among them such as the upper-middle class status of many Chicanos). Usually Chicano essentializing narratives apply to Anglos as well, ignoring their ethnic and class differences, "Anglo" or "White" in the Southwest being a residual category that encompasses anybody of European origin - Jews, Irish, Germans, Italians, etc.—who is neither Mexican nor Black..

In any case, this cultural and identitarian totalizing pretension does not allow one to perceive the relevance of a concept that is of the utmost importance in any political struggle: the concept of alliance, i.e., the articulation of interests and differences.

In Posadas-Encarnación, like many other borders, there is a narrative myth of similarity shared by many people that claims, "The border doesn't exist," that "we were integrated forever." The problem starts when researchers accept social actors' discourses as a description of reality instead of as a particular position regarding reality. In the Ciudad Juárez-El Paso case, something very similar occurs, but in the opposite direction: peoples' discourse of difference is also a positioning in relation to the border. The problem is that no matter what the actors say, it is possible that the border does not exist for some things and does exist for other things. In fact, in Posadas and Ciudad Juárez some social actors sustained such a theory: the border exists from an economic or commercial point of view, as is evident in the commercial disputes in the region, but does not exist from a cultural, symbolic, or emotional point of view. But other social actors maintain that the border also exists from a cultural and symbolic point of view, and that they never would accept being equated with Encarnacenos or El Pasoans.

In contrast not only to the diplomatic rhetoric, but also to the regional integrationist discourses, the striking feature of the Posadas-Encarnación border is that all the actors involved in the conflict, in some sense or another share a central concern: everybody wants the border. The problem, the struggle, is to establish the kind of border and its connotations. To make ends meet, and perhaps to go up in the social scale, for many people it implies the maximization of border benefits.

Though the ensuing statement will require a particular analysis of each social sector in different circumstances, we could advance, provisionally, the following scheme: paseras (whose job is buying where it is cheaper and selling where it is more expensive) work and make a living out of the border. They are menaced by both a strict customs control and an absolute "integration" expressed in the disappearance of price differentials between shores. Paseras and taxi drivers perform work that is the exclusive consequence of this everyday invention that is the border. For that reason, the first historical account we have about paseras goes back to the precise moment in which the international boundary is defined and Posadas grows as a city. Paradoxically, the paseras jobs are the byproduct of the nation-state, at the same time that the state becomes (through its customs controls) the very limit — many times traumatic — of their jobs.

In similar fashion, the formal and informal merchants of those cities that, historically or

6. Operation Blockade in El Paso was supported by more than 70 percent of Mexican American El Pasoans; Proposition 187 in California, was voted for by nearly 40 percent of the state's Hispanics. 
momentarily, have lower prices, are also very interested in maintaining the price differentials that increase their sales. Therefore, who are the most hindered by the border? In these quintessentially commercial cities, the most hampered are the formal merchants of the (historically or temporarily) more expensive cities, for instance, Posadas. Nevertheless, they do not request the disappearance of the border, but instead ask for a strict customs control against "contrabando hormiga." That is, they want the border to be more powerful, not to disappear.

The entrepreneurs who cannot compete with foreign goods want more taxes for imported products, that is, more customs control, more "frontiers." On the other hand, the entrepreneurs who can compete with foreign goods want both the elimination of taxes and the border itself because they benefit from the conquering of external markets. When some economic conditions change, however, those who have demanded an opening of the national economy, those who have clamored for the "end of borders," start to demand protectionist policies of a different sort. At the same time, all these economic positionings are processed in terms of identity that nationalize or regionalize conflicts. At this level, local, national, and regional histories, as well as national state policies regarding the neighboring countries and the different local actors, take center stage. In this context, the discourse of brotherhood and the nonexistence of borders should be considered as a way to relate to, in, and throughout the border.

In the Ciudad Juárez-El Paso area something similar occurs. There are several economic actors that benefit or are harmed by the existence of the border, but the more striking feature of that border is the level of animosity that exists between social actors who, according to the hegemonic version of North American border studies (e.g., G.Anzaldúa 1987; A.Paredes 1978; R.Rosaldo 1989; J.D.Saldívar 1997) were always considered brothers.

To what U.S.-Mexico border are academicians influenced by Anzaldúa, Rosaldo, and the like referring? Surely not Ciudad Juárez-El Paso:

We may consider "border identities" as "created out of empathy for others by means of a passionate connection through difference. Such a connection is furthered by a narrative imagination that enables critical linkage to be made between our own stories and the stories of cultural others" [Peter McLaren, cited in M.Harrison and M.Montoya 1998:652].

The U.S.-Mexico border [is] a paradigm of crossing, circulation, material mixing, and resistance. [J.D.Saldívar 1997:13].

How can we understand the following testimonies, using the romantic version of the border supported by these academicians?

Rosario: I'm telling you! Now many illegal immigrants complain that the government wants to take their children out of school. I say that is O.K. . . I also suffered a lot in Mexico, as a child I suffered a lot, but I say it is not fair to take away our children's benefits to give them to those who are not . . . legally here in the U.S. . . . Our kids are getting less and less supplies and services and I do not think that is fair, either! The problem is that before there were less people, right now there is no room for more people here [P.Vila 2000:160].

Felipe: I get very mad . . . and I always ... I don't know if all of those who live here, who were born here think . . . "If I were a ruler, I'd stop all the arrival of people [from the interior of Mexico] here" . . . I mean control it . . . do it in almost the same manner as the United States is doing it, make a kind of border [P.Vila 2000:35].

How can you make compatible the two sentences that follow? "The borderlands, then, are a place 


\section{Alejandro Grimson and Pablo Vila}

of abjection and exhilaration; a place where the person is 'crisscrossed by multiple identities,' where we are a "plural self, one that thrives on ambiguity and multiplicity"' (M.Harrison and M.Montoya 1998:652). What kind of "multiple identities," "plurality of the self," and "ambiguity and multiplicity" are present in Mexican-American border patrol agents (the majority of such agents in El Paso), who, like Alicia, express the following:

Alfredo: And my aunt [Alicia], the one in immigration, she says crazy things

like: I hate 'em, I hate 'em, I hate 'em! [laughs] And she's become so bitter, so

embittered with her job and what she sees that she'll say, I am not Mexican!

[laughs] ... so talk about confusion ...

Fanny: And my daughter says, Alicia, excuse me, you are Mexican! [laughs].

Alfredo: And she says, No I'm not! [laughs] [P.Vila 2000:121].

How can Alicia reconcile her own version of the border with Harrison and Montoya's borderlands that encourage "empathy for others by means of a passionate connection through difference"? As Heyman correctly points out, "a facile idea — at the border, two sides equal one hybrid - replaces analysis. By no means do we have sensitive enough ethnography or testimony at the border to declare that it is experienced through a hybrid subjectivity or identity" (1994:47).

\section{Conclusions}

The problem is that in much recent border scholarship, there is a general failure to pursue the theoretical possibility that fragmentation of experience can lead to the reinforcement of borders instead of an invitation to cross them. Thus, crossing borders, and not reinforcing borders, is the preferred metaphor in the current hegemonic version of border studies and theory. As Heyman points out (1994:46): "the weight of the border image is on the cultural, the notion of two sides, two meanings, facing each other, rather than on the power, the idea of a forcible mode of territorial control. Without denying either aspect, I worry about emphasizing the former over the latter."

This article attempted to show that when one does "sensitive enough ethnographies" on the border, the picture one gets is much more complex than that displayed by the metaphors of integration from below, the blurring of national frontiers, the hybrid, and the like.

We have analyzed how the discourse of the eternal brotherhood of people many times hides power relations between different cities, populations, and states. At the same time, the discourse of the complete social and cultural difference conceals similarities. In this article we have analyzed two well-demarcated aspects of this difference-similarity dyad, the first focusing on the economic dimension of regional integration in the Encarnación-Posadas case, and the second highlighting the identity dimension of such an integration. We say this with the understanding that all processes of economic integration have, of course, a symbolic aspect, and that identity processes have an economic dimension as well.

Different aspects of the globalization and regionalization processes intervene in the contemporary redefinitions of borders. Several social actors and institutions that seem to dilute themselves according to the postmodern grand narratives, take diverse positions regarding those processes. The interests of different states and social sectors, as well as their diverse positionings in terms of identity, processed in a complex web of disputes, alliances and conflicts, are currently remaking and resignifying borders. In this context, the neglect of the border reinforcers by the hegemonic version of border studies has started to show its limits.

\section{References}

Abinzano, Roberto.

1993. Mercosur: un Modelo de Integración. Posadas and Buenos Aires: Editorial 
Forgotten Border Actors: the Border Reinforcers

Universitaria. Universidad Nacional de Misiones.

Anzaldúa, Gloria.

1987. Borderlands/La Frontera: The New Mestiza. San Francisco: Aunt Lute Books.

Bhabha, Homi K.

1994. The Location of Culture. New York: Rutledge.

Calderón, Hector, and Jose David Saldívar (editors).

1991. Criticism in the Borderlands. Studies in Chicano Literature, Culture, and Ideology.

Durham: Duke University Press.

Cheater, A.P.

1998. Transcending the State?: Gender and Borderline Constructions of Citizenship in

Zimbabwe. In Border Identities. Thomas Wilson and Hasting Donnan, editors. New York:

Cambridge University Press, pp.191-214.

Clementi, Hebe (editor).

1996. La Dimensión Cultural del MERCOSUR. Buenos Aires: CEA-CBC-UBA.

Cook, Scott.

1998. Mexican Brick Culture in the Building of Texas, 1800s-1980s. College Station:

Texas A \& M Univesity Press.

2002. Rethinking Penny Capitalism. Studies in Labor.

2003. Alienation and Commodity Culture South of the Border. Unpublished manuscript. Ferradas, Carmen.

1998. Power in the Southern Cone Borderlands: An Anthropology of Development

Practice. Westport, Connecticut: Bergin and Garvey.

Gomez-Peña, Guillermo.

1988. Documented/Undocumented. In The Graywolf Annual Five: Multi-Cultural

Literacy. Rick Simonson and Scott Walker, editors. St. Paul, Minnesota: Graywolf, p. 130.

1991. Border Brujo. In Being América: Essays on Art, Literature, and Identity from Latin

America. Rachel Weiss and Alan West, editors. Fredonia, N.Y.: White Pine, pp.194-236.

Gordillo, Gastón.

2000. Canales Para un Río Indómito. Frontera, Estado y Utopías Aborígenes En El

Noroeste de Formosa. In Fronteras, Naciones e Identidades. Alejandro Grimson, editor.

Buenos Aires: CICCUSLa Crujía, pp. 232-255.

Gordillo, Gastón, and Juan Martín Leguizamón

1999. El Río y la Frontera: Aborígenes, Obras Públicas, y Mercosur en el Pilcomayo.

Buenos Aires: Editorial Universitaria de Buenos Aires.

Grimson, Alejandro

1998. La Producción Mediática de Nacionalidad en la Frontera. Documentos de Discusión $\mathrm{n}^{\circ}$ 26. Paris: MOST/UNESCO.

2000. Fronteras, Naciones e Identidades. Buenos Aires, Ciccus-La Crujía.

2002. El Otro lado del Río. Periodistas, Nación y Mercosur en la Frontera. Buenos Aires: Eudeba.

Gutierrez, David.

1995. Walls and Mirrors: Mexican Americans, Mexican Immigrants, and the Politics of Ethnicity. Berkeley: University of California Press.

Harrison, Melissa, and Margaret E. Montoya.

1998. Voices/Voces in the Borderlands. In The Latino Condition. A Critical Reader. 
Alejandro Grimson and Pablo Vila

Richard Delgado and Jean Stefancic, editors. New York: New York University Press, pp. 649-660.

Heyman, Josiah.

1994. The Mexico-United States Border in Anthropology: A Critique and Reformulation. Journal of Political Ecology 1:43-65.

2001. Class and Classification at the U.S.Mexico Border. Human Organization 60 (2).

2002 U.S. Immigration Officers of Mexican Ancestry as Mexican Americans, Citizens, and Immigration Police, Current Anthropology 43 (2002):479-507.

Hicks, Emily.

1991 Border Writing: The Multidimensional Text. Minneapolis: University of Minnesota Press.

Howard, Cheryl, Irma Carrillo, and Sylvia Peregrino.

1994. Operation Blockade: a Tale of Two Cities. Paper presented at the Western Social Science Association, April 22, Albuquerque, New Mexico.

Klein, Alan M.

1997. Baseball on the Border. A Tale of Two Laredos. Princeton, N.J.: Princeton University Press.

Martínez, Oscar.

1978. Border Boom Town. Ciudad Juárez since 1848. Austin and London: University of Texas Press.

1994. Border People: Life and Society in the U.S.-Mexico Borderlands. Tucson: The University of Arizona Press.

Mazzei, Enrique.

1999. Rivera (Uruguay)-Sant`Ana (Brasil): Integración e Identidad Fronteriza. Paper Presented at Seminario Internacional Fronteras, Naciones e Identidades, May 27, Buenos Aires, Argentina.

Oviedo, Alejandro, and Javier Gortari.

1997. Misiones en el Intercambio Económico Regional y en el Contexto del Mercosur. Estudios Regionales 10, FHYCS-UNaM.

Paredes, Américo.

1978. The Problem of Identity in a Changing Culture: Popular Expressions of Culture Conflict Along the Lower Rio Grande Border. In Views Across the Border: The United States and Mexico. Stanley R. Ross, editor. Albuquerque: University of New Mexico Press, pp. 68-94.

Peña, Manuel.

1985. The Texas-Mexican Conjunto. History of a Working-Class Music. Austin: University of Texas Press.

1999. The Mexican American Orquesta: Music, Culture, and the Dialectic of Conflict. Austin: University of Texas Press.

Recondo, Gregorio (editor).

1997. Mercosur. La Dimensión Cultural de la Integración. Buenos Aires: CICCUS.

Ribeiro, Gustavo Lins.

1994. Transnational Capitalism and Hydropolitics in Argentina: The Yacireta High Dam. Gainesville: University of Florida Press.

Rosaldo, Renato.

1989. Culture and Truth: The Remaking of Social Analysis. Boston: Beacon Press. 
Forgotten Border Actors: the Border Reinforcers

Sahlins, Peter.

1989. Boundaries: The Making of France and Spain in the Pyrenees. Berkeley and Los Angeles: University of California Press.

Saldívar, Jose David.

1997. Border Matters. Remapping American Cultural Studies. Berkeley: University of California Press.

Sánchez, George.

1995. Becoming Mexican American: Ethnicity, Culture and Identity in Chicano Los

Angeles, 1900-1945. New York: Oxford University Press.

Spener, David, and Kathy Staudt (editors).

1998. The U.S.-Mexico Border: Transcending Division, Contesting Identities. Boulder, Co: Lynne Rienner Publishers.

Tonkin, Elizabeth

1994. Borderline questions: People and Space in West Africa. In Border Approaches.

Anthropological Perspectives on Frontiers, Hasting Donnan and Thomas Wilson, editors. London: University Press of America and Anthropological Association of Ireland, pp. $15-30$.

Various Authors.

1997a. O Mercosul e a Integraçao Sul/Americana: Mais do que a Economia. Encontro de Culturas. Brasília: Fundação Alexandre Gusmão.

Various Authors.

1997b. Mercosur: un Atlas Cultural, Social y Económico. Buenos Aires: Instituto Herbert Levy y Manrique Zago Ediciones.

Vélez-Ibáñez, Carlos G.

1996. Border Visions: Mexican Cultures of the Southwest United States. Arizona: University of Arizona Press.

Vidal, Hernan.

1998. Frontera y Nación Después del Ajuste. De la Producción de Soberanía a la Producción de Ciudadanía en Río Turbio. Cuadernos para el Debate nº 1 . Buenos Aires: IDES.

Vila, Pablo.

1996. Catholicism and Identity in the U.S.-México Border. El Paso: University of Texas at El Paso. Chicano Studies. Occasional Papers In Chicano Studies Number 8.

1997. Narrative Identities: The Emplotment of the Mexican on the U.S.-Mexico Border. The Sociological Quarterly 38 (1): 147-183.

1998. The Competing Meanings of the Label Chicano in El Paso. In The U.S.-Mexico Border: Transcending Division, Contesting Identities. David Spener and Kathy Staudt, editors. Boulder, Co: Lynne Rienner Publishers, pp. 185-211.

2000. Crossing Borders. Reinforcing Borders: Social Categories and Narrative Identities on the U.S.-Mexico Frontier. Austin: University of Texas Press.

2003 Ethnography at the Border. Minneapolis: Minnesota University Press.

Wilson, Thomas, And Hasting Donnan (editors).

1998. Border Identities. New York: Cambridge University Press. 
Alejandro Grimson and Pablo Vila

Abstract: This article is a critique of two different types of essentialisms that have gained
widespread acceptance in places as distant as the U.S.-Mexico border and different Mercosur
frontiers. Both essentialisms rely on metaphors that refer to the concept of "union," and put their
emphasis on a variety of "sisterhood/brotherhood" tropes and, in particular, the "crossing"
metaphor. This kind of stance tends to make invisible the social and cultural conflict that many
times characterizes political frontiers. The article wants to reinstall this conflictive dimension. In
that regard, we analyze two different case studies. The first is the history of a bridge constructed
between Posadas, Argentina and Encarnación, Paraguay. The second is the community reaction
toward an operation implemented by the Border Patrol in 1993 ("Operation Blockade") in a border
that for many years was considered an exemplar of the "good neighbor relationships" between
Mexico and the United States, the frontier between El Paso and Ciudad Juárez.

Key Words: U.S.-Mexico border, Operation Blockade, Mercosur frontier, political frontier, Argentina, Paraguay, Mexico, United States, Posadas, El Paso , Encarnación, Ciudad Juárez, Border Patrol.

Résumé : Cet article fait une critique de deux espèces d'essentialisme qui ont gagné une acceptation à travers des endroits aussi éloignés que la frontière entre les Etats-Unis et le Mexique et les frontières Mercosur. Les deux types d'essentialisme se basent sur des métaphores d'union avec l'emphase sur une variété de tropes de fraternité/sororité et en particulier sur des métaphores de la traversée des frontières. Ce genre de position a une tendance de rendre invisible les conflits sociaux et culturels qui sont souvent la norme sur les frontières. Cet article propose de rétablir la dimension conflictuelle. Dans cet égard, nous faisons l'analyse de deux cas. Le premier est l'histoire d'un pont construit entre Posadas (Argentine) et Encarnación (Paraguay). Le deuxième cas est la réaction de la communauté par rapport à une opération de la Border Patrol (Patrouille de la Frontière) en 1993 (Operation Blockade) sur une frontière, qui depuis longtemps a été considéré un modèle des relations "good neighbor" (bon voisin), entre El Paso et Ciudad Juárez.

Mots clefs : frontière Etats-Unis - Mexique, les Etats-Unis, le Mexique, Operation Blockade, frontière Mercosur, frontière politique, Argentine, Paraguay, Posadas, El Paso, Encarnación, Ciudad Juárez, Border Patrol.

Resumen: Este artículo es una crítica a dos tipos de esencialismos que son ampliamente aceptados en lugares tan distantes como las fronteras de Estados Unidos-México y los diversos límites del Mercosur. Ambos esencialismos se apoyan en metáforas que aluden a la "unión", enfatizan tropos de "hermandad" y, en particular, refieren a la metáfora del "cruce". Este tipo de postura ha hecho invisible los conflictos sociales y culturales que muchas veces caracterizan a las fronteras políticas. El artículo busca reinstalar una visión conflictiva. Para ello, analizamos dos estudios de caso. El primero es la historia de un puente construido entre Posadas, Argentina y Encarnación, Paraguay. El segundo es la reacción de la comunidad hacia una operación implementada por la Patrulla Fronteriza en 1993 ("Operation Blockade") en una frontera que por muchos años fue considerada un ejemplo de "buenas relaciones de vecindad" entre México y Estados Unidos, la frontera entre El Paso y Ciudad Juárez.

Palabres claves : las fronteras de Estados Unidos-México, Operation Blockade, Argentina, Paraguay, México, Estados Unidos Posadas, El Paso, Encarnación, Ciudad Juárez, la Patrulla Fronteriza. 